\title{
Use of the North American Nursing Diagnosis Association taxonomies, Nursing Intervention Classification, Nursing Outcomes Classification and NANDA-NIC-NOC linkage in cardiac rehabilitation
}

\author{
Anna Maria Iannicelli ${ }^{1 *}$, Pasquale De Matteo $^{2 *}$, Daniele Vito ${ }^{1}$, Elisa Pellecchia ${ }^{2}$, Concetta Dodaro ${ }^{3}$, \\ Francesco Giallauria ${ }^{2}$, Carlo Vigorito ${ }^{2}$ \\ ${ }^{1}$ Department of Translational Medical Sciences, Federico II University of Naples; ${ }^{2}$ Division of Internal Medicine \\ (Metabolic and Cardiac Rehabilitation Unit), Federico II University of Naples; ${ }^{3}$ Department of Advanced Biomedical \\ Sciences, Federico II University of Naples, Italy; "These Authors equally contributed to the work.
}

\begin{abstract}
This study aims at creating a standardized language for each patient admitted to Cardiac Rehabilitation Unit (CR) by identifying nursing diagnosis, interventions, results/objectives expected and related correlations. The primary outcome was identifying health needs of all patients admitted to CR. The secondary outcomes were the identification of North American Nursing Diagnosis Association -International diagnoses (NANDA-I), of nursing intervention classification (NIC), of nursing outcomes classification (NOC) and their correlation NANDA-NIC-NOC linkage (NNN linkage) in order to define a standardized language for all nursing staff. This is a retrospective study involving a sample of 168 patients discharged from CR. The NANDA-I, the NIC, the NOC and the most frequently used NNN connections were identified and collected by using structured form including the 11 functional models of Marjory Gordon. Data from 76 patients were analyzed $(92.1 \%$ male; mean age $( \pm$ SD) $62.7 \pm 9$ yrs; IQ range: $42-82$ ). The main NANDA-I nursing diagno-
\end{abstract}

Correspondence: Anna Maria Iannicelli, Department of Translational Medical Sciences, University of Naples Federico II, Via Pansini 5, 80131 Naples, Italy. Tel: + 39.081.746.4559 - Fax: + 39.081.746.4559. E-mail: annamaria.iannicelli@unina.it

Contributions: PDM, EP, AMI, conception and design of the work, data acquisition, analysis and interpretation; DV, EP, data acquisition and analysis; FG, CD, CV, data analysis and interpretation, manuscript draft, critical review of the final draft.

Key words: NANDA; NIC; NOC; taxonomies; cardiac rehabilitation; nursing.

Conflict of interest: the authors declare no conflict of interest.

Received for publication: 14 March 2019.

Accepted for publication: 2 May 2019.

(C) Copyright A.M. Iannicelli et al., 2019

Licensee PAGEPress, Italy

Monaldi Archives for Chest Disease 2019; 89:1060

doi: 10.4081/monaldi.2019.1060

This article is distributed under the terms of the Creative Commons Attribution Noncommercial License (by-nc 4.0) which permits any noncommercial use, distribution, and reproduction in any medium, provided the original author(s) and source are credited. sis belongs to psychological sphere, but not to physiological domains. The statement NIC has allowed to put into practice actions of health prevention and education.

Nursing care documentation and NNN taxonomic language promotes a wide diffusion of nursing discipline culture and significant qualitative improvement of patient's care, further improving the communication between nurses and other health professionals.

\section{Introduction}

Cardiac rehabilitation (CR) program exerts several beneficial effects reducing mortality [1,2], preventing cardiac remodeling [3,4], and improving cardiovascular functional capacity and myocardial perfusion [5-8]. The improvement of endothelial function [8], the anti-inflammatory properties $[9,10]$, the improvement of neurohormonal and autonomic balance [11-18] might be at the basis of the mechanisms by which exercise training exerts its beneficial effects.

Standardized care terminology plays a key role in nursing care [19]. The knowledge of the basic concepts in nursing practice, of the nursing staff roles, of the care theories and legal problems, could improve nursing interventions and outcomes in different settings [20]. These standardized terminologies are necessary for the execution of nursing care plans, especially in case of use of nursing record [21]. Previous evidences suggest that the nursing record must include nursing diagnoses, interventions and outcomes to totally reflect the entire nursing process [22].

The aims of this study are to identify the health needs of patients, the identification of NANDA-International diagnoses (NANDA-I) [23]; of nursing intervention classification (NIC) [24]; of nursing outcomes classification (NOC) [25] and their correlation (NNN linkage), in order to define standardized language for all nursing staff [26]. In addition, the 11 functional models of Marjory Gordon have been used as functional model of global of global assessment of care assistance [27].

\section{Patients and Methods}

Data from patients admitted to the CR unit at the "Federico II" University of Naples were analyzed retrospectively. In this study were analyzed a total of 168 patients admitted from January 1, 2016 to December 31, 2016. The inclusion criteria defined were: 1. Medical diagnosis of previous acute myocardial infarction 
(AMI) (ICD-9 412) or the presence of coronary angioplasty (ICD9 V4582) or post-surgical status of aortocoronary by-pass (ICD-9 V4581); 2. No age limit; 3. No distinction of sex (Table 1). Exclusion criteria were defined as: 1 . Patients with events following the previous IMA; 2 . Not adherence to the trial; 3 . Non-adhesion to cardiological rehabilitation (ICD-9 V612); 4. Patients who have performed less than 10 accesses to day-hospital and patients who have performed more than 50 accesses (Table 1). Subjects who met these criteria were included in the study constituting a sample of 76 [92.1\% male; mean age ( \pm SD) $65 \pm 12$ yrs] patients out of a total of 168 patients in the entire population. Inclusion/exclusion criteria were ascertained by CR nurse team.

In overall population, the most detected ICD-9 codes are: (ICD9 codes 2703/2720/2722/2750) Metabolism disorders detected 45 times; (25000/25002/25050) Diabetes mellitus 14 times; (27800/27801/27802) Overweight and obesity 7 times; (412) Previous myocardial infarction 76 times; (4110/4111/4149) Acute coronary syndrome 57 times; (4011/4019) Hypertension 35 times; (4280/4289) Congestive heart failure 13 times; (40210) Benign hypertensive heart disease 24 times; (41401) Coronary atherosclerosis of native coronary artery 24 times; (43310) Occlusion and steno- sis of the carotid without mention of heart attack 23 times; (44020/44021/44381) Atherosclerosis of native arteries of the limbs and other peripheral angiopathies 11 times; (V4581/V4582) Postsurgical status of aorto-coronary bypass and angioplasty 56 times; (5560/5718/53051/53370/53510/56200/57420) Digestive system disorders 8 times and (60000/60090) Prostate disorders 13 times.

All clinical charts were evaluated with the use of a nursing record built for the specific study, structured with the Marjory Gordon' 11 functional models [27], and containing the NANDA-I taxonomy for the formulation of nursing diagnoses [23], the NOC taxonomy for the identification of outcomes and measurable result indicators [25], and the NIC taxonomy for the identification of nursing interventions and the respective activities [24].

\section{Statistics}

Descriptive statistics are given in terms of mean value \pm standard deviation (SD). Comparison between variables were made using Student t-test. All data were collected in a specific database

Table 1. Gordon's functional models of health.

N. Models
$1 \quad$ Health perception and Management

\begin{tabular}{ll}
2 & Nutritional metabolic \\
\hline$\quad$ Elimination
\end{tabular}

$4 \quad$ Activity exercise

\begin{tabular}{ll}
\hline 5 & Sleep rest \\
6 & Cognitive-perceptual \\
\hline 7 & \\
& Self perception/self concept
\end{tabular}

$7 \quad$ Self perception/self concept

\begin{tabular}{ll}
8 & Role relationship \\
\hline 9 & Sexuality reproductive \\
10 & Coping-stress tolerance \\
\hline 11 & Value-belief pattern
\end{tabular}

\section{Data detected}

- $5 \%$ of patient smoked before the event.

- $60 \%$ of patients report drinking mild wine or alcohol (a glass at lunch in an interval of time from every day to once a week).

- $18 \%$ of the patients did not carry out medical checks before the event.

- The remaining $82 \%$ of patients practiced periodic checks and all adhered to prescribed medical treatment and all independently.

- $4 \%$ of patients report being affected by allergies (drugs, dust, food, etc.).

- $4 \%$ of patients were obese and $18 \%$ overweight.

- $18 \%$ are affected by diabetes mellitus.

- $59 \%$ of patients are affected by metabolic disorders

- In addition, 14 patients report gastro-intestinal disorders.

- $11.8 \%$ of patients report prostate problems with related urinary urination problems.

- $2.6 \%$ of patients report kidney stones.

- During exercise, $30 \%$ of the assisted patients report shortness of breath (walk, climb stairs, ride a bicycle) and $10 \%$ report breathlessness even at rest.

- $25 \%$ report feeling tired and $15 \%$ feeling tired.

- $\mathrm{SpO}_{2}$ is altered in 8 patients for airway diseases and in patients with COPD.

- A small proportion of patients, extrapolated from the total sample, claim to have awaken during sleep.

- Two patients report hypoacusia.

- Two patients report retinopathy/glaucoma.

- Three patients have dementia with impaired intellectual functions.

- $\quad 40 \%$ have difficulty making decisions.

- Most patients have a correct perception of their physical as well as cognitive and emotional abilities.

- $4 \%$ have a negative attitude towards their value, gender identity and their body image.

- $78 \%$ report a sense of anxiety and restlessness (fear of a new event).

- Signs of anxiety and fear are noticed in non-verbal signals in all patients. In particular, in some, from the eye contact, one notices discouragement and surrender.

- Most patients live in the family.

- $40 \%$ are workers, $40 \%$ are retired, $20 \%$ has not declared status.

- $20 \%$ of the assisted persons also refer to a family member (caregiver) in the communication between the health-patient.

- $100 \%$ have positive interaction with health personnel.

- $13 \%$ of those assisted express concern about their sexuality after the event.

- $90 \%$ showed functional adaptability to situations and habitual behavior in dealing with any problem.

- $40 \%$ showed ability to use problem solving.

- Most patients needed psychological support for anxiety/depression management.

- Nobody has declared information about life and spiritual values and convictions. 
and all analyses were conducted by using SPSS, version 25.0 for Windows (SPSS Inc., Chicago, IL, USA).

\section{Results}

Data from clinical records of 76 patients were analyzed [92.1\% males; mean age ( \pm SD) $65 \pm 12$ years]. Table 1 shows Gordon's functional models of health detected. The frequencies of NANDAI, NIC, NOC and NNN-linkage were also reported:

\section{North American Nursing Diagnosis Association - International (NANDA-I)}

NANDA-I nursing diagnoses detected in the 76 patients enrolled $(n=460)$ are described and subdivided into domains and classes (Table 2). The most relevant nursing diagnoses belong to the domains:

- Domain 2: Nutrition (18.3\%);

- Domain 4: Activities and rest (21.5\%);

- Domain 9: Coping tolerance to stress (25.4\%);

- Domain 11: Security/Protection (16.1\%).
In detail, the most frequently NANDA-I nursing diagnoses identified were "anxiety" (00146), that was detected in $78.9 \%$ of subjects, followed by "availability to improve feeding" (00163) reported in $73.7 \%$ of cases $68 \%$ ), and "impaired physical mobility" (00085), that was detected in $38.2 \%$ of patients.

\section{Nursing Outcomes Classification (NOC)}

The most frequently outcomes (NOCs) selected $(n=1381)$ are reported in Table 3 and they belong to the following domains:

- Domain 2: Physiological health (35\%);

- Domain 3: Psychosocial health (27.9\%);

- Domain 4: Knowledge related to health and behavior (17.4\%). The main reported NOC is the "coping" (1302), detected 84 times, the second was the "self-control of fear" (1404), that was collected 77 times. Instead, the "nutritional status" (1004) and the "weight control" (1612) were detected 68 times.

\section{Nursing intervention classification (NIC)}

The detected interventions (NICs) $(n=1708)$ are provided in Table 4. They are subdivided in the following domains:

- Domain 1: Basic Physiological (31.8\%);

- Domain 2: Complex physiological (15.8\%)

Table 2. NANDA-I diagnoses.

\begin{tabular}{|c|c|c|c|c|}
\hline Domain (\%) & Class & Nursing diagnosis & $\mathbf{N}$ & $\%$ \\
\hline Health promotion(2.60\%) & Health management & $\begin{array}{l}\text { Frail elderly syndrome (00257) } \\
\text { Ineffective health maintenance (00099) } \\
\text { Risk-prone health behavior (00188) }\end{array}$ & $\begin{array}{l}5 \\
3 \\
4\end{array}$ & $\begin{array}{l}1.1 \\
0.7 \\
0.9\end{array}$ \\
\hline Nutrition(18.26\%) & $\begin{array}{l}\text { Ingestion } \\
\text { Metabolism }\end{array}$ & $\begin{array}{l}\text { Readiness for enhanced nutrition (00163) } \\
\text { Obesity (00232) } \\
\text { Overweight (00233) } \\
\text { Risk for overweight (00234) } \\
\text { Risk for unstable blood glucose level (00179) }\end{array}$ & $\begin{array}{c}56 \\
6 \\
1 \\
5 \\
16\end{array}$ & $\begin{array}{l}12.2 \\
1.3 \\
0.2 \\
1.1 \\
3.5\end{array}$ \\
\hline Elimination and exchange (0.86\%) & Respiratory function & Impaired gas exchange (00030) & 4 & 0.9 \\
\hline Activity/rest(21.52\%) & $\begin{array}{l}\text { Sleep/Rest } \\
\text { Activity/Exercise } \\
\text { Energy balance } \\
\text { Cardiovascular/Pulmonary responses }\end{array}$ & $\begin{array}{l}\text { Disturbed sleep pattern (00198) } \\
\text { Impaired physical mobility (00085) } \\
\text { Fatigue (00093) } \\
\text { Decresed cardiac output (00029) } \\
\text { Risk for decresed cardiac output (00240) } \\
\text { Activity intolerance (00092) } \\
\text { Ineffective peripheral tissue perfusion (00204) } \\
\text { Risk for Ineffective peripheral tissue perfusion (00228) }\end{array}$ & $\begin{array}{c}1 \\
29 \\
5 \\
16 \\
18 \\
7 \\
5 \\
18\end{array}$ & $\begin{array}{l}0.2 \\
6.3 \\
1.1 \\
3.5 \\
3.9 \\
1.5 \\
1.1 \\
3.9\end{array}$ \\
\hline Self -perception (7.82 \%) & $\begin{array}{l}\text { Self-concept } \\
\text { Self-esteem } \\
\text { Body image }\end{array}$ & $\begin{array}{l}\text { Readiness for enhanced hope (00185) } \\
\text { Risk for situational low self-esteem (00153) } \\
\text { Disturbed body image (00118) }\end{array}$ & $\begin{array}{l}13 \\
13 \\
10\end{array}$ & $\begin{array}{l}2.8 \\
2.8 \\
2.2\end{array}$ \\
\hline Role relationship (0.83\%) & $\begin{array}{l}\text { Caregiving role } \\
\text { Role performance }\end{array}$ & $\begin{array}{l}\text { Caregiver role strain (00061) } \\
\text { Impaired social interaction (00052) }\end{array}$ & $\begin{array}{l}3 \\
1\end{array}$ & $\begin{array}{l}0.7 \\
0.2\end{array}$ \\
\hline Coping/Stress Tolerance (25.43\%) & Coping response & $\begin{array}{l}\text { Fear (00148) } \\
\text { Anxiety (00146) } \\
\text { Defensive coping (00071) } \\
\text { Compromised family coping (00074) } \\
\text { Chronic sorrow (00137) }\end{array}$ & $\begin{array}{c}17 \\
60 \\
23 \\
16 \\
1\end{array}$ & $\begin{array}{c}3.7 \\
13.0 \\
5.0 \\
3.5 \\
0.2\end{array}$ \\
\hline Life principles (1.74\%) & Value/belief/action congruence & Decisional conflict (00083) & 8 & 1.7 \\
\hline Safety/protection (16.08\%) & $\begin{array}{l}\text { Infection } \\
\text { Physical injury }\end{array}$ & $\begin{array}{l}\text { Risk for infection (00004) } \\
\text { Risk for injury (00035) } \\
\text { Risk for corneal injury (00245) } \\
\text { Impaired tissue integrity (00044) } \\
\text { Risk for urinary tract injury (00250) } \\
\text { Risk for peripheral neurovascular dysfunction (00086) }\end{array}$ & $\begin{array}{c}14 \\
23 \\
2 \\
14 \\
17 \\
4\end{array}$ & $\begin{array}{l}3.0 \\
5.0 \\
0.4 \\
3.0 \\
3.7 \\
0.9\end{array}$ \\
\hline Comfort (4.78\%) & Physical comfort & Impaired comfort (00214) & 22 & 4.8 \\
\hline Total & & & 460 & 100 \\
\hline
\end{tabular}


Table 3. NOC label.

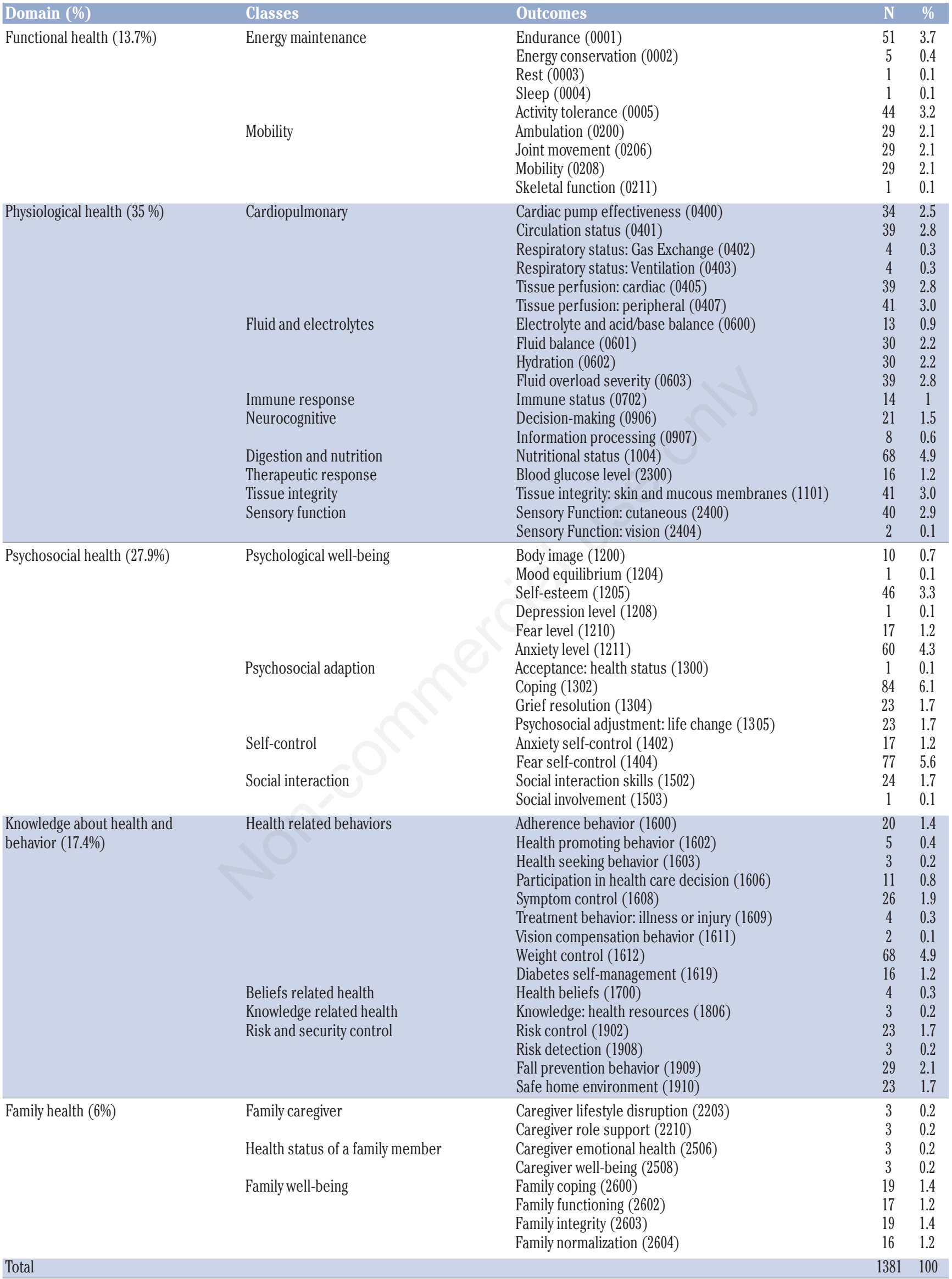


- Domain 3: Behavior (40.3\%);

- Domain 4: Security (12.1\%).

In particular, the main NIC was "Exercise promotion" (0200) that appeared 104 times, the second was "anxiety reduction" (5820), detected 85 times and the third is "nutrition management" (1100) reported 84 times.

\section{NNN linkage}

According with the results previously reported, in Table 5 is shown the number of "NNN linkages" for the main NANDA-I diagnoses. It should be highlighted that even if the sample analyzed was composed of 76 subjects, some interventions exceed the sample number; this happens because NICs are interventions that apply to the individual NOC and not to the single subject. For example, the NIC "Promotion of physical activity" appeared 104 times, every time that an objective has as intervention the promotion of physical activity; similar results were observed for all other NIC selected and analyzed.

\section{Discussion}

The use of standardized terminology, applied to nursing charts, retrieves and facilitates the Evidence Based Nursing [28]. The analysis of the data collected from Gordon's functional models allowed the evaluation and the enunciation of nursing diagnoses; the evaluation and analysis of the objectives that must be achieved and the evaluation and execution of interventions useful for achieving the pre-established objectives.

The first data that emerges clearly and strongly is the state of concern that patient's experience. This status, plus the apprehen- sion of cohabiting family members, creates a situation of tension, which must be managed at best. Thus, it is important to inform both the patient and the caregiver about the state of health and the rehabilitation process of the patient, to reassure everyone and to start an adequate health education. In this way, the caregivers will give they will give the right support to the person by becoming the managers of the care of their loved ones. Then, it could be justified the reason why the most relevant NANDA-I diagnoses belong to the psychological sphere and not to the physiological domains.

Anxiety (00146), defensive coping (00071), impaired wellbeing (00214) are the most frequent diagnoses in the analyzed cohort, and to these have been linked the more appropriate NOCs and NICs have been linked.

In cardiology setting, Park et al. [29] analyzed 272 patients diagnosed with acute heart failure to determine nursing diagnoses, the results to be followed and the interventions to be implemented. Authors reported the following nursing diagnoses: knowledge deficit (00126), reduced cardiac output (0029), risk of injury (00035) and inefficient airway release (00031). These four nursing diagnoses represented the $50 \%$ of the total of nursing diagnoses described in the study. In addition, the same study expressed as predominant domains security/protection domain (27.8\%), activity/rest (22.8\%), perception/cognition (15.7\%) and elimination and exchange (12.6\%); the most used classes were cardiovascular/pulmonary responses (21.9\%), physical injuries (17.1\%) and cognition (15\%); while domains like coping/stress tolerance and health promotion have been poorly mentioned [29].

Moreover, Chiappinotto et al. [30] analyzed data on a cohort of 20 patients with a diagnosis of post-acute heart failure founding further nursing diagnoses: anxiety (00146), compromised wellbeing (00214) and intolerance to activity (00092). In a retrospec-

Table 4. NIC label.

\begin{tabular}{|c|c|c|c|c|}
\hline Domain (\%) & Classes & Intervention & $\mathbf{N}$ & $\%$ \\
\hline \multirow[t]{15}{*}{ Physiological: basic (32\%) } & \multirow[t]{6}{*}{ Activity and exercise management } & Body mechanics promotion (0140) & 39 & 2.2 \\
\hline & & Energy management $(0180)$ & 56 & 3.1 \\
\hline & & Exercise promotion (0200) & 104 & 5.7 \\
\hline & & Exercise promotion: strength training (0201) & 41 & 2.3 \\
\hline & & Exercise therapy: ambulation (0221) & 29 & 1.6 \\
\hline & & Exercise therapy: joint mobility (0224) & 29 & 1.6 \\
\hline & Elimination management & Urinary elimination management (0590) & 17 & 0.9 \\
\hline & Immobility management & Positioning (0840) & 70 & 3.9 \\
\hline & \multirow[t]{5}{*}{ Nutrition support } & Eating disorders management (1030) & 16 & 0.9 \\
\hline & & Nutrition management (1100) & 84 & 4.6 \\
\hline & & Nutritional management (1160) & 56 & 3.1 \\
\hline & & Weight management (1260) & 12 & 0.7 \\
\hline & & Weight reduction assistance (1280) & 3 & 0.2 \\
\hline & \multirow[t]{2}{*}{ Self-care facilitation } & Eye care $(1650)$ & 2 & 0.1 \\
\hline & & Sleep enhancement (1850) & 13 & 0.7 \\
\hline \multirow[t]{13}{*}{ Physiological: complex (15\%) } & \multirow[t]{2}{*}{ Electrolyte and acid-base management } & Fluid/electrolyte management (2080) & 17 & 0.9 \\
\hline & & Hyperglycemia management (2120) & 16 & 0.9 \\
\hline & \multirow[t]{3}{*}{ Drug management } & Medication administration: oral (2304) & 16 & 0.9 \\
\hline & & Medication administration: subcutaneous (2317) & 16 & 0.9 \\
\hline & & Medication management (2380) & 29 & 1.6 \\
\hline & Neurologic management & Peripheral sensation management (2660) & 41 & 2.3 \\
\hline & \multirow[t]{3}{*}{ Respiratory management } & Airway management (3140) & 4 & 0.2 \\
\hline & & Airway insertion and stabilization (3210) & 4 & 0.2 \\
\hline & & Respiratory monitoring (3350) & 4 & 0.2 \\
\hline & Skin/wound management & Wound care $(3660)$ & 14 & 0.8 \\
\hline & \multirow[t]{3}{*}{ Tissue perfusion management } & Cardiac care: rehabilitative (4046) & 39 & 2.2 \\
\hline & & Cardiac care: arterial insufficiency (4062) & 41 & 2.3 \\
\hline & & Cardiac care: venous insufficiency (4066) & 41 & 2.3 \\
\hline
\end{tabular}

To be continued on next page 
tive study conducted in a small hospital in the northeast of Italy [31], the NANDA, NIC and NOC standard terminology have been applied to the nursing record in patients with chronic heart disease. Interestingly, Authors reported that nurses in Cardiac Rehabilitation care are aware of patient problems and are able to design a personalized care project. The main limitation is attention to physiological treatments; however, paying more attention to psychological problems and improvements in self-care may confer great improvement in nursing care. Furthermore, family and community care should be involved in patient's care more actively. In addition, NANDA-I, NOC and NIC taxonomies offer good coverage of cardiac rehabilitation nursing care, deemed of great utility as outlined by all cardiac nurses participating in rehabilitation care.

In the present study, all patients were affected from chronic or post-acute heart failure, and in these subjects the most common nursing diagnoses was fear (indicated 17 times), anxiety (60), defensive coping (23) and compromising coping of the family (16) of the coping domain tolerance to stress $(25.4 \%)$. These results suggest that patients after an acute and sudden cardiovascular event had more anxiety and fear regarding the possible occurrence of a new future event. Therefore, cardiac patient tends to be more attentive to the symptoms that may occur and try to seek treatment strategies aimed to safeguarding the actual state of health.

The prescription of the CR can be explained through the NANDA-I diagnoses of reduced cardiac output (00029), reduced cardiac output risk (00240), intolerance to activity (00092), ineffective perfusion of peripheral tissues (00204) and risk of ineffective perfusion of peripheral tissues (00228), to which the NOC results and appropriate NIC interventions (listed in Table 5) have been linked. The more detected NICs are exercise promotion (0200) and reduction of the anxiety (5820). In addition, NICs of counseling (5240), active listening (4920), nutrition management (1100) and nutritional management (1160) have been enunciated, translating into practice the works for prevention and health education.

Table 4. Continued from previous page.

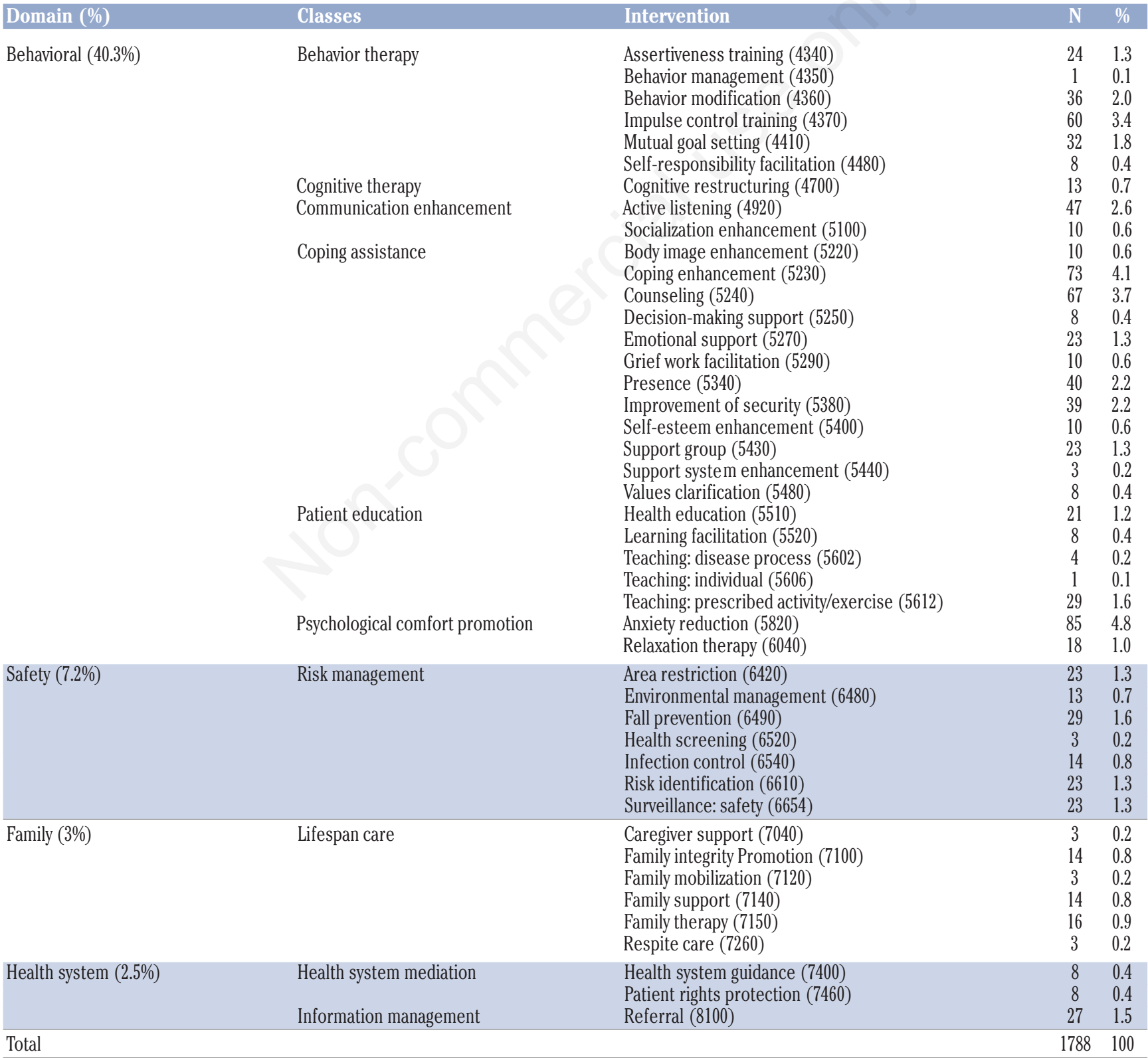


Table 5. NNN linkage.

\begin{tabular}{|c|c|c|c|c|c|c|c|c|}
\hline NAND & & $\mathrm{n}$ & NOC & & $\mathrm{n}$ & & NIC & n \\
\hline 00257 & Frail elderly syndrome & 5 & $\begin{array}{l}0005 \\
0001 \\
0401 \\
0405 \\
0603\end{array}$ & $\begin{array}{l}\text { Activity tolerance } \\
\text { Endurance } \\
\text { Circulation status } \\
\text { Tissue perfusion: cardiac } \\
\text { Fluid overload severity }\end{array}$ & $\begin{array}{l}5 \\
5 \\
5 \\
5 \\
5\end{array}$ & $\begin{array}{l}0201 \\
0200 \\
0180 \\
1850 \\
4410 \\
0140 \\
4046 \\
5380 \\
6480 \\
5100\end{array}$ & $\begin{array}{l}\text { Exercise promotion: strength training } \\
\text { Exercise promotion } \\
\text { Energy management } \\
\text { Sleep enhancement } \\
\text { Mutual goal setting } \\
\text { Body mechanics promotion } \\
\text { Cardiac care: rehabilitative } \\
\text { Improvement of security } \\
\text { Environmental management } \\
\text { Socialization enhancement }\end{array}$ & $\begin{array}{l}5 \\
5 \\
5 \\
5 \\
5 \\
5 \\
5 \\
5 \\
5 \\
5\end{array}$ \\
\hline 00099 & Ineffective health maintenance & 3 & $\begin{array}{l}1602 \\
1603 \\
1806 \\
1606 \\
1908\end{array}$ & $\begin{array}{l}\text { Health promoting behavior } \\
\text { Health seeking behavior } \\
\text { Knowledge: health resources } \\
\text { Participation in health care decision } \\
\text { Risk detection }\end{array}$ & $\begin{array}{l}3 \\
3 \\
3 \\
3 \\
3\end{array}$ & $\begin{array}{l}5510 \\
4480 \\
6520 \\
1280\end{array}$ & $\begin{array}{l}\text { Health education } \\
\text { Self-responsibility facilitation } \\
\text { Health screening } \\
\text { Weight reduction assistance }\end{array}$ & $\begin{array}{l}3 \\
3 \\
3 \\
3\end{array}$ \\
\hline 00188 & Risk-prone health behavior & 4 & $\begin{array}{l}1600 \\
1700 \\
1609 \\
1608\end{array}$ & $\begin{array}{l}\text { Adherence behavior } \\
\text { Health beliefs } \\
\text { Treatment behavior: illness or injury } \\
\text { Symptom control }\end{array}$ & $\begin{array}{l}4 \\
4 \\
4 \\
4\end{array}$ & $\begin{array}{l}5510 \\
4410 \\
4480 \\
5602\end{array}$ & $\begin{array}{l}\text { Health education } \\
\text { Mutual goal setting } \\
\text { Self-responsibility facilitation } \\
\text { Teaching: disease process }\end{array}$ & $\begin{array}{l}4 \\
4 \\
4 \\
4\end{array}$ \\
\hline 00163 & Readiness for enhanced nutrition & 56 & $\begin{array}{l}1004 \\
1612 \\
\end{array}$ & $\begin{array}{l}\text { Nutritional status } \\
\text { Weight control }\end{array}$ & $\begin{array}{l}56 \\
56 \\
\end{array}$ & $\begin{array}{l}1100 \\
1160\end{array}$ & $\begin{array}{l}\text { Nutrition management } \\
\text { Nutritional management }\end{array}$ & $\begin{array}{l}56 \\
56\end{array}$ \\
\hline 00232 & Obesity & 6 & $\begin{array}{l}1004 \\
1612\end{array}$ & $\begin{array}{l}\text { Nutritional status } \\
\text { Weight control }\end{array}$ & $\begin{array}{l}6 \\
6\end{array}$ & $\begin{array}{l}1100 \\
1260 \\
5606 \\
4360 \\
0200\end{array}$ & $\begin{array}{l}\text { Nutrition management } \\
\text { Weight management } \\
\text { Teaching: individual } \\
\text { Behavior modification } \\
\text { Exercise promotion }\end{array}$ & $\begin{array}{l}6 \\
6 \\
6 \\
6 \\
6\end{array}$ \\
\hline 00233 & Overweight & 1 & $\begin{array}{l}1004 \\
1612\end{array}$ & $\begin{array}{l}\text { Nutritional status } \\
\text { Weight control }\end{array}$ & $\begin{array}{l}1 \\
1\end{array}$ & $\begin{array}{l}1100 \\
1260 \\
5606 \\
4360 \\
0200\end{array}$ & $\begin{array}{l}\text { Nutrition management } \\
\text { Weight management } \\
\text { Teaching: individual } \\
\text { Behavior modification } \\
\text { Exercise promotion }\end{array}$ & $\begin{array}{l}1 \\
1 \\
1 \\
1 \\
1\end{array}$ \\
\hline 00234 & Risk for Overweight & 5 & $\begin{array}{l}1004 \\
1602\end{array}$ & $\begin{array}{l}\text { Nutritional status } \\
\text { Health promoting behavior }\end{array}$ & $\begin{array}{l}5 \\
5\end{array}$ & $\begin{array}{l}1100 \\
1260 \\
5606 \\
4360 \\
0200\end{array}$ & $\begin{array}{l}\text { Nutrition management } \\
\text { Weight management } \\
\text { Teaching: individual } \\
\text { Behavior modification } \\
\text { Exercise promotion }\end{array}$ & $\begin{array}{l}5 \\
5 \\
5 \\
5 \\
5\end{array}$ \\
\hline 00179 & $\begin{array}{l}\text { Risk for unstable bloof } \\
\text { glucose level }\end{array}$ & 16 & $\begin{array}{l}2300 \\
1600 \\
1619\end{array}$ & $\begin{array}{l}\text { Blood glucose level } \\
\text { Adherence behavior } \\
\text { Diabetes self-management }\end{array}$ & $\begin{array}{l}16 \\
16 \\
16\end{array}$ & $\begin{array}{l}1030 \\
1100 \\
2120 \\
2304 \\
2317 \\
2380\end{array}$ & $\begin{array}{l}\text { Eating disorders management } \\
\text { Nutrition management } \\
\text { Hyperglycemia management } \\
\text { Medication administration: oral } \\
\text { Medication administration: subcutaneous } \\
\text { Medication management }\end{array}$ & $\begin{array}{l}16 \\
16 \\
16 \\
16 \\
16 \\
16\end{array}$ \\
\hline 00030 & Impaired gas exchange & 4 & $\begin{array}{l}0402 \\
0403\end{array}$ & $\begin{array}{l}\text { Respiratory status: gas exchange } \\
\text { Respiratory status: ventilation }\end{array}$ & $\begin{array}{l}4 \\
4\end{array}$ & $\begin{array}{l}0180 \\
0200 \\
3140 \\
3210 \\
3350\end{array}$ & $\begin{array}{l}\text { Energy management } \\
\text { Exercise promotion } \\
\text { Airway management } \\
\text { Airway insertion and stabilization } \\
\text { Respiratory monitoring }\end{array}$ & $\begin{array}{l}4 \\
4 \\
4 \\
4 \\
4\end{array}$ \\
\hline 00198 & Disturbed sleep pattern & 1 & $\begin{array}{l}0003 \\
0004 \\
0211\end{array}$ & $\begin{array}{l}\text { Rest } \\
\text { Sleep } \\
\text { Skeletal function }\end{array}$ & $\begin{array}{l}1 \\
1 \\
1\end{array}$ & $\begin{array}{l}0180 \\
1850 \\
6040 \\
0200 \\
6480\end{array}$ & $\begin{array}{l}\text { Energy management } \\
\text { Sleep enhancement } \\
\text { Relaxion therapy } \\
\text { Exercise promotion } \\
\text { Environmental management }\end{array}$ & $\begin{array}{l}1 \\
1 \\
1 \\
1\end{array}$ \\
\hline 00085 & Impaired physical mobility & 29 & $\begin{array}{l}0200 \\
0206 \\
0208 \\
1909\end{array}$ & $\begin{array}{l}\text { Ambulation } \\
\text { Joint movement } \\
\text { Mobility } \\
\text { Fall prevention behavior }\end{array}$ & $\begin{array}{l}29 \\
29 \\
29 \\
29\end{array}$ & $\begin{array}{l}0224 \\
0201 \\
0221 \\
0840 \\
5612 \\
6490\end{array}$ & $\begin{array}{l}\text { Exercise promotion: joint mobility } \\
\text { Exercise promotion: strength training } \\
\text { Exercise promotion: ambulation } \\
\text { Positioning } \\
\text { Teaching: prescribed exercise } \\
\text { Fall prevention }\end{array}$ & $\begin{array}{l}29 \\
29 \\
29 \\
29 \\
29 \\
29\end{array}$ \\
\hline 00093 & Fatigue & 5 & $\begin{array}{l}0005 \\
0001 \\
0002\end{array}$ & $\begin{array}{l}\text { Activity tolerance } \\
\text { Endurance } \\
\text { Energy conservation }\end{array}$ & $\begin{array}{l}5 \\
5 \\
5\end{array}$ & $\begin{array}{l}0180 \\
6480 \\
4410 \\
5100\end{array}$ & $\begin{array}{l}\text { Energy management } \\
\text { Environmental management } \\
\text { Mutual goal setting } \\
\text { Socialization enhancement }\end{array}$ & $\begin{array}{l}5 \\
5 \\
5 \\
5\end{array}$ \\
\hline
\end{tabular}

To be continued on next page 
Table 5. Continued from previous page.

\begin{tabular}{|c|c|c|c|c|c|c|c|c|}
\hline NAND & & n & NOC & & n & & NIC & n \\
\hline 00029 & Decreased cardiac output & 16 & $\begin{array}{l}0001 \\
0005 \\
0400 \\
0401 \\
0405 \\
0603\end{array}$ & $\begin{array}{l}\text { Endurance } \\
\text { Activity tolerance } \\
\text { Cardiac pump effectiveness } \\
\text { Circulation status } \\
\text { Tissue perfusion: cardiac } \\
\text { Fluid overload severity }\end{array}$ & $\begin{array}{l}16 \\
16 \\
16 \\
16 \\
16 \\
16\end{array}$ & $\begin{array}{l}0140 \\
0180 \\
0200 \\
4046 \\
5380\end{array}$ & $\begin{array}{l}\text { Body mechanics promotion } \\
\text { Energy management } \\
\text { Exercise promotion } \\
\text { Cardiac care: rehabilitative } \\
\text { Improvement of security }\end{array}$ & $\begin{array}{l}16 \\
16 \\
16 \\
16 \\
16\end{array}$ \\
\hline 00240 & Risk for decreased cardiac output & 18 & $\begin{array}{l}0001 \\
0005 \\
0400 \\
0401 \\
0405 \\
0603\end{array}$ & $\begin{array}{l}\text { Endurance } \\
\text { Activity tolerance } \\
\text { Cardiac pump effectiveness } \\
\text { Circulation status } \\
\text { Tissue perfusion: cardiac } \\
\text { Fluid overload severity }\end{array}$ & $\begin{array}{l}18 \\
18 \\
18 \\
18 \\
18 \\
18\end{array}$ & $\begin{array}{l}0140 \\
0180 \\
0200 \\
4046 \\
5380\end{array}$ & $\begin{array}{l}\text { Body mechanics promotion } \\
\text { Energy management } \\
\text { Exercise promotion } \\
\text { Cardiac care: rehabilitative } \\
\text { Improvement of security }\end{array}$ & $\begin{array}{l}18 \\
18 \\
18 \\
18 \\
18\end{array}$ \\
\hline 00092 & Activity intolerance & 7 & 0005 & Activity tolerance & 7 & $\begin{array}{l}0201 \\
0200 \\
0180 \\
1850 \\
4410\end{array}$ & $\begin{array}{l}\text { Exercise promotion: strength training } \\
\text { Exercise promotion } \\
\text { Energy management } \\
\text { Sleep enhancement } \\
\text { Mutual goal setting }\end{array}$ & $\begin{array}{l}7 \\
7 \\
7 \\
7 \\
7\end{array}$ \\
\hline 00204 & $\begin{array}{l}\text { Ineffective peripheral tissue } \\
\text { perfusion }\end{array}$ & 5 & $\begin{array}{l}2400 \\
1101 \\
0407\end{array}$ & $\begin{array}{l}\text { Sensori-function: tactile } \\
\text { Tissue integrity: skin and membranes } \\
\text { Tissue perfusion: peripheral }\end{array}$ & $\begin{array}{l}5 \\
5 \\
5\end{array}$ & $\begin{array}{l}2660 \\
4066 \\
4062 \\
0840 \\
0200\end{array}$ & $\begin{array}{l}\text { Peripheral sensation management } \\
\text { Cardiac care: venous insufficiency } \\
\text { Cardiac care: arterial insufficiency } \\
\text { Positioning } \\
\text { Exercise promotion }\end{array}$ & $\begin{array}{l}5 \\
5 \\
5 \\
5 \\
5\end{array}$ \\
\hline 00228 & $\begin{array}{l}\text { Risk for ineffective peripheral } \\
\text { tissue perfusion }\end{array}$ & 18 & $\begin{array}{l}2400 \\
1101 \\
0407\end{array}$ & $\begin{array}{l}\text { Sensori-function: tactile } \\
\text { Tissue integrity: skin and membranes } \\
\text { Tissue perfusion: peripheral }\end{array}$ & $\begin{array}{l}18 \\
18 \\
18\end{array}$ & $\begin{array}{l}2660 \\
4066 \\
4062 \\
0840 \\
0200\end{array}$ & $\begin{array}{l}\text { Peripheral sensation management } \\
\text { Cardiac care: venous insufficiency } \\
\text { Cardiac care: arterial insufficiency } \\
\text { Positioning } \\
\text { Exercise promotion }\end{array}$ & $\begin{array}{l}18 \\
18 \\
18 \\
18 \\
18\end{array}$ \\
\hline 00185 & Readiness for enhanced hope & 13 & $\begin{array}{l}0601 \\
0602 \\
0600\end{array}$ & $\begin{array}{l}\text { Fluid balance } \\
\text { Hydration } \\
\text { Electrolyte and acid/base balance }\end{array}$ & $\begin{array}{l}13 \\
13 \\
13\end{array}$ & 2080 & Fluid/electrolyte management & 13 \\
\hline 00153 & $\begin{array}{l}\text { Risk for situational low } \\
\text { self-esteem }\end{array}$ & 13 & $\begin{array}{l}0906 \\
1304 \\
1305 \\
1205\end{array}$ & $\begin{array}{l}\text { Decision making } \\
\text { Grief resolution } \\
\text { Psychosocial adjustment: life change } \\
\text { Self-esteem }\end{array}$ & $\begin{array}{l}13 \\
13 \\
13 \\
13\end{array}$ & $\begin{array}{l}4920 \\
5340 \\
5240 \\
4700 \\
7140 \\
5430 \\
5230\end{array}$ & $\begin{array}{l}\text { Active listening } \\
\text { Presence } \\
\text { Counseling } \\
\text { Cognitive restructuring } \\
\text { Family support } \\
\text { Support group } \\
\text { Coping enhancement }\end{array}$ & $\begin{array}{l}13 \\
13 \\
13 \\
13 \\
13 \\
13 \\
13\end{array}$ \\
\hline 00118 & Disturbed body image & 10 & $\begin{array}{l}1200 \\
1304 \\
1205 \\
1305\end{array}$ & $\begin{array}{l}\text { Body image } \\
\text { Grief resolution } \\
\text { Self-esteem } \\
\text { Psychosocial adjustment: life change }\end{array}$ & $\begin{array}{l}10 \\
10 \\
10 \\
10\end{array}$ & $\begin{array}{l}5400 \\
5240 \\
5340 \\
4920 \\
5220 \\
5290 \\
5430 \\
8100\end{array}$ & $\begin{array}{l}\text { Self-esteem enhancement } \\
\text { Counseling } \\
\text { Presence } \\
\text { Active listening } \\
\text { Body image enhancement } \\
\text { Grief work facilitation } \\
\text { Support group } \\
\text { Referral }\end{array}$ & $\begin{array}{l}10 \\
10 \\
10 \\
10 \\
10 \\
10 \\
10 \\
10\end{array}$ \\
\hline 00061 & Caregiver role strain & 3 & $\begin{array}{l}2508 \\
2203 \\
2506 \\
2210 \\
2600 \\
2603\end{array}$ & $\begin{array}{l}\text { Caregiver well-being } \\
\text { Caregiver lifestyle disruption } \\
\text { Caregiver emotional health } \\
\text { Caregiver role support } \\
\text { Family coping } \\
\text { Family integrity }\end{array}$ & $\begin{array}{l}3 \\
3 \\
3 \\
3 \\
3 \\
3\end{array}$ & $\begin{array}{l}7040 \\
7260 \\
5230 \\
7120 \\
4410 \\
5440\end{array}$ & $\begin{array}{l}\text { Caregiver support } \\
\text { Respite care } \\
\text { Coping enhancement } \\
\text { Family mobilization } \\
\text { Mutual goal setting } \\
\text { Support system enhancement }\end{array}$ & $\begin{array}{l}3 \\
3 \\
3 \\
3 \\
3 \\
3\end{array}$ \\
\hline 00052 & Impaired social interaction & 1 & $\begin{array}{l}2602 \\
1502 \\
1503\end{array}$ & $\begin{array}{l}\text { Family functioning } \\
\text { Social interaction skills } \\
\text { Social involvement }\end{array}$ & $\begin{array}{l}1 \\
1 \\
1\end{array}$ & $\begin{array}{l}4360 \\
7100 \\
5240 \\
4350 \\
7140 \\
4480\end{array}$ & $\begin{array}{l}\text { Behavior modification } \\
\text { Family integrity promotion } \\
\text { Counseling } \\
\text { Behavior management } \\
\text { Family support } \\
\text { Self-responsibility facilitation }\end{array}$ & $\begin{array}{l}1 \\
1 \\
1 \\
1 \\
1 \\
1\end{array}$ \\
\hline 00148 & Fear & 17 & $\begin{array}{l}1402 \\
1210 \\
1404\end{array}$ & $\begin{array}{l}\text { Anxiety self-control } \\
\text { Fear level } \\
\text { Fear self-control }\end{array}$ & $\begin{array}{l}17 \\
17 \\
17\end{array}$ & $\begin{array}{l}5820 \\
5230 \\
5340 \\
5240 \\
6040\end{array}$ & $\begin{array}{l}\text { Anxiety reduction } \\
\text { Coping enhancement } \\
\text { Presence } \\
\text { Counseling } \\
\text { Relaxion therapy }\end{array}$ & $\begin{array}{l}17 \\
17 \\
17 \\
17 \\
17\end{array}$ \\
\hline
\end{tabular}

To be continued on next page 


\section{Conclusions}

This study showed that the use of a care planning created according to Marjory Gordon's model, and the NANDA, the NIC and NOC taxonomic language, applied to $\mathrm{CR}$, is able to satisfy the health needs on the patient' physiological and psychosocial sphere. This is possible thanks to the safety, quality, and the constant and continue care of the nursing assistance to the patients. It should be emphasized that taking care of the person requires that the nurse must be fully present. The nurse could have the possibility to express their own in-depth scientific theoretical knowledge, critical thinking, clinical professional competence, and to independently evaluate the situation, in order to take the best decisions for the patient's safety and health, in full responsibility. Finally, a careful listening through a dialogue, allows to guarantee personalized assistance, able to carefully plan, manage and implement nursing interventions in line with the expected health results, reinforcing the attention to psychological, spiritual and emotional aspects in a logic of sharing the care plan with the patient. The use of an assistance documentation, of the NANDA, NIC and NOC taxonomies in CR setting, as well as improving communication between nurses

Table 5. Continued from previous page.

\begin{tabular}{lllll}
\hline NANDA-I & n & NOC & \\
00146 & Anxiety & 60 & 1211 & Anxiety level \\
& & & 1302 & Coping \\
& & 1404 & Fear self-control \\
\hline \multirow{2}{*}{00071} & Defensive coping & 23 & 1302 & Coping \\
& & & 1205 & Self-esteem \\
& & 1502 & Social interaction skills
\end{tabular}

\begin{tabular}{|c|c|c|c|c|c|c|c|c|}
\hline & & & & & & 4360 & Behavior modification & 23 \\
\hline 00074 & Compromised family coping & 16 & $\begin{array}{l}2600 \\
2602 \\
2603 \\
2604\end{array}$ & $\begin{array}{l}\text { Family coping } \\
\text { Family functioning } \\
\text { Family integrity } \\
\text { Family normalization }\end{array}$ & $\begin{array}{l}16 \\
16 \\
16 \\
16\end{array}$ & $\begin{array}{l}5230 \\
7100 \\
7150 \\
5240 \\
8100\end{array}$ & $\begin{array}{l}\text { Coping enhancement } \\
\text { Family integrity promotion } \\
\text { Family therapy } \\
\text { Counseling } \\
\text { Referral }\end{array}$ & $\begin{array}{l}16 \\
16 \\
16 \\
16 \\
16\end{array}$ \\
\hline 00137 & Chronic sorrow & 1 & $\begin{array}{l}1208 \\
1302 \\
1204 \\
1300\end{array}$ & $\begin{array}{l}\text { Depression level } \\
\text { Coping } \\
\text { Mood equilibrium } \\
\text { Acceptance: health status }\end{array}$ & $\begin{array}{l}1 \\
1 \\
1 \\
1\end{array}$ & $\begin{array}{l}5230 \\
8100 \\
4920 \\
4340\end{array}$ & $\begin{array}{l}\text { Coping enhancement } \\
\text { Referral } \\
\text { Active listening } \\
\text { Assertiveness training }\end{array}$ & $\begin{array}{l}16 \\
1 \\
1 \\
1\end{array}$ \\
\hline 00083 & Decisional conflict & 8 & $\begin{array}{l}0906 \\
0907 \\
1606\end{array}$ & $\begin{array}{l}\text { Decision making } \\
\text { Information processing } \\
\text { Participation in health care decision }\end{array}$ & $\begin{array}{l}8 \\
8 \\
8\end{array}$ & $\begin{array}{l}5250 \\
4410 \\
5520 \\
7400 \\
7460 \\
5480 \\
5820\end{array}$ & $\begin{array}{l}\text { Decision making support } \\
\text { Mutual goal setting } \\
\text { Learning facilitation } \\
\text { Health system guidance } \\
\text { Patient rights protection } \\
\text { Values clarification } \\
\text { Anxiety reduction }\end{array}$ & $\begin{array}{l}8 \\
8 \\
8 \\
8 \\
8 \\
8 \\
8\end{array}$ \\
\hline 00004 & Risk for infection & 14 & 0702 & Immune status & 14 & $\begin{array}{l}6540 \\
3660 \\
5510\end{array}$ & $\begin{array}{l}\text { Infection control } \\
\text { Wound care } \\
\text { Health education }\end{array}$ & $\begin{array}{l}14 \\
14 \\
14\end{array}$ \\
\hline 00035 & Risk for injury & 23 & $\begin{array}{l}1910 \\
1902\end{array}$ & $\begin{array}{l}\text { Self-home environment } \\
\text { Risk control }\end{array}$ & $\begin{array}{l}19 \\
19\end{array}$ & $\begin{array}{l}6420 \\
6654 \\
6610\end{array}$ & $\begin{array}{l}\text { Area restriction } \\
\text { Surveillance: safety } \\
\text { Risk identification }\end{array}$ & $\begin{array}{l}19 \\
19 \\
19\end{array}$ \\
\hline 00245 & Risk for corneal injury & 2 & $\begin{array}{l}1602 \\
1611 \\
2404\end{array}$ & $\begin{array}{l}\text { Health promoting behavior } \\
\text { Vision compensation behavior } \\
\text { Sensori-function: vision }\end{array}$ & $\begin{array}{l}2 \\
2 \\
2\end{array}$ & $\begin{array}{l}6480 \\
1650\end{array}$ & $\begin{array}{l}\text { Environmental management } \\
\text { Eye care }\end{array}$ & $\begin{array}{l}2 \\
2\end{array}$ \\
\hline 00044 & Impaired tissue integrity & 14 & $\begin{array}{l}2400 \\
1101 \\
0407\end{array}$ & $\begin{array}{l}\text { Sensori-function: tactile } \\
\text { Tissue integrity: skin and membranes } \\
\text { Tissue perfusion: peripheral }\end{array}$ & $\begin{array}{l}14 \\
14 \\
14\end{array}$ & $\begin{array}{l}2660 \\
4062 \\
4066 \\
0840 \\
0200\end{array}$ & $\begin{array}{l}\text { Peripheral sensation management } \\
\text { Cardiac care: arterial insufficiency } \\
\text { Cardiac care: venous insufficiency } \\
\text { Positioning } \\
\text { Exercise promotion }\end{array}$ & $\begin{array}{l}14 \\
14 \\
14 \\
14 \\
14\end{array}$ \\
\hline 00250 & Risk for urinary tract injury & 17 & $\begin{array}{l}0601 \\
0602\end{array}$ & $\begin{array}{l}\text { Fluid balance } \\
\text { Hydration }\end{array}$ & $\begin{array}{l}17 \\
17\end{array}$ & $\begin{array}{l}0590 \\
2080\end{array}$ & $\begin{array}{l}\text { Urinary elimination management } \\
\text { Fluid/electrolyte management }\end{array}$ & $\begin{array}{l}17 \\
17\end{array}$ \\
\hline 00086 & $\begin{array}{l}\text { Risk for peripheral neurovascular } \\
\text { dysfunction }\end{array}$ & 4 & $\begin{array}{l}2400 \\
1101 \\
0407\end{array}$ & $\begin{array}{l}\text { Sensori function: tactile } \\
\text { Tissue integrity: skin and membranes } \\
\text { Tissue perfusion: peripheral }\end{array}$ & $\begin{array}{l}4 \\
4 \\
4\end{array}$ & $\begin{array}{l}2660 \\
4062 \\
4066 \\
0840 \\
0200\end{array}$ & $\begin{array}{l}\text { Peripheral sensation management } \\
\text { Cardiac care: arterial insufficiency } \\
\text { Cardiac care: venous insufficiency } \\
\text { Positioning } \\
\text { Exercise promotion }\end{array}$ & $\begin{array}{l}4 \\
4 \\
4 \\
4 \\
4\end{array}$ \\
\hline 00214 & Impaired comfort & 22 & 1608 & Symptom control & 22 & & & \\
\hline
\end{tabular}

N NIC n

$60 \quad 5820$ Anxiety reduction 60

$60 \quad 4370$ Impulse control training 60

$23 \quad 5230$ Coping enhancement 23

235240 Counseling 23

235240 Counseling

$23 \quad 5270$ Emotional support 23

4920 Active listening 23

4340 Assertiveness training 23

4360 Behavior modification 23

7100 Family integrity promotion

7150 Family therapy

240 Counseling

5230 Coping enhancement 16

8100 Referral 1

4920 Active listening

4340 Assertiveness training

5250 Decision making suppor

4410 Mutual goal setting

5520 Learning facilitation

7460 Patient rights protection

5480 Values clarification

5820 Anxiety reduction

Infection control

660 Wound care

6420 Area restriction 19

6654 Surveillance: safety 19

6480 Environmental management 2

650 Eye care 2

1611 Vision compensation behavior

2400 Sensori-function: tactile 14

1101 Tissue integrity: skin and membranes 14

07 Tissue perfusion: peripheral 14 
and other health professionals, promotes both the development of research and the dissemination of culture and nursing discipline, both the qualitative improvement of the assistance. In this way, the nurse could adopt different strategies for health management of each patient (education, counseling, cardiovascular risk modification, lifestyle modification) for reducing cardiovascular risks and preventing newer acute cardiovascular events.

In conclusion, nursing care documentation and NNN taxonomic language promotes a wide diffusion of nursing discipline culture and significant qualitative improvement of patient's care, further improving the communication between nurses and other health professionals.

\section{References}

1. Rauch B, Riemer T, Schwaab B, et al. Short-term comprehensive cardiac rehabilitation after AMI is associated with reduced 1-year mortality: results from the OMEGA study. Eur J Prev Cardiol 2014;21:1060-9.

2. Pedretti RFE, Fattirolli F, Griffo R, et al. Cardiac Prevention and Rehabilitation "3.0": From acute to chronic phase. Position Paper of the Italian Association for Cardiovascular Prevention and Rehabilitation (GICR-IACPR). Monaldi Arch Chest Dis 2018;88:1004.

3. Giallauria F, Lucci R, D'Agostino M, et al. Left ventricular remodeling in patients with moderate systolic dysfunction after myocardial infarction: favorable effects of exercise training and predictive role of $\mathrm{N}$-terminal pro-brain natriuretic peptide. Eur J Cardiovasc Prev Rehabil 2008;15:113-8.

4. Giallauria F, Lucci R, Maresca L, et al. Favorable effects of exercise-based cardiac rehabilitation after acute myocardial infarction on left atrial remodeling. Int $\mathrm{J}$ Cardiol 2009;136:300-6.

5. Giallauria F, Lucci R, Mancini M, et al. Two-year multicomprehensive secondary prevention program: favourable effects on cardiovascular functional capacity and coronary risk profile after acute myocardial infarction. J Cardiovasc Med (Hagerstown) 2009;10:772-80.

6. Giannuzzi P, Balestroni G, Ceci V, et al. Global secondary prevention strategies to limit event recurrence after myocardial infarction. Arch Intern Med 2008;168:2194-204.

7. Giallauria F, Maresca L, Mancini M, et al. Effects of exercise training started within 2 weeks after acute myocardial infarction on myocardial perfusion and left ventricular function: a gated SPECT imaging study. Eur J Prev Cardiol 2012;19:1410-9.

8. Giallauria F, Torella G, Lucci R, et al. Exercise training early after acute myocardial infarction reduces stress-induced hypoperfusion and improves left ventricular function. Eur J Nucl Med Mol Imaging.2013;40:315-24.

9. Tarro Genta F, Eleuteri E, Temporelli PL, et al. Flow-mediated dilation normalization predicts outcome in chronic heart failure patients. J Card Fail 2013;19:260-7.

10. Giallauria F, Vitelli A, Pacileo M, et al. Effects of exercise training on high-mobility group box-1 levels after acute myocardial infarction. J Card Fail 2011;17:108-14.

11. Cirillo P, Giallauria F, Vigorito C, et al. Increased high mobility group box-1 protein levels are associated with impaired cardiopulmonary and echocardiographic findings after acute myocardial infarction. J Card Fail 2009; 15:362-7.

12. Giallauria F, Lucci R, Psaroudaki M, et al. Long-term effects of cardiac rehabilitation on end-exercise heart rate recovery after myocardial infarction. Eur J Cardiovasc Prev Rehabil 2006;13:544-50.

13. Giallauria F, Lucci R, D'Agostino M, et al. Exercise-based cardiac rehabilitation improves heart rate recovery in elderly patients after acute myocardial infarction. J. Gerontol A Biol Sci Med Sci 2006;61:713-7.

14. Giallauria F, De Lorenzo A, Lucci R, et al. Reduction of NTpro-BNP levels with exercise-based cardiac rehabilitation in patients with left ventricular dysfunction after myocardial infarction. Eur J Cardiovasc Prev Rehabil 2006;13:625-32.

15. Giallauria F, Lucci R, Vigorito C, et al. Favourable effects of exercise training on $\mathrm{N}$-terminal pro-brain natriuretic peptide plasma levels in elderly patients after acute myocardial infarction. Age Ageing 2006;35:601-7.

16. Smart N, Meyer T, Butterfield J, et al. Individual patient metaanalysis of exercise training effects on systemic brain natriuretic peptide expression in heart failure. Eur J Prev Cardiol 2012;19:428-435.

17. Vitale G, Romano G, Di Franco A, et al. Early effects of sacubitril/valsartan on exercise tolerance in patients with heart failure with reduced ejection fraction. J Clin Med 2019;8 pii: E262.

18. Rengo G, Galasso G, Femminella GD, et al. Reduction of lymphocyte G protein-coupled receptor kinase-2 (GRK2) after exercise training predicts survival in patients with heart failure. Eur J Prev Cardiol 2014;21:4-11.

19. Rutherford M. Standardized nursing language: What does it mean for nursing practice? OJIN 2008;13:1-12.

20. Toroddsen A, Ehnfors M. Putting policy into practice: Preposttests of implementing standardized languages for nursing documentation. J Clin Nurs 2007;16:1826-38.

21. Westra BL, Delany CW, Konicek D, Keenan G. Nursing standards to support the electronic health record. Nurs Oulook 2008;56:258-66.

22. Von Krogh G, Dale C, Naden D. A framework for integrating NANDA, NIC and NOC terminology in electronic patient records. J Nurs Scholarship 2005;37:275-81.

23. NANDA International, Inc. Nursing diagnosis 2015-2017: Definitions and classification. Ames: Wiley-Blackwell; 2014.

24. McCloskey Dochterman J, Bulechek G, Butcher H. Nursing interventions classification (NIC). Iowa City: Elsevier; 2008.

25. Moorhead S, Johnson M, Maas ML, Swanson E. Nursing outcomes classification (NOC). Iowa City: Elsevier; 2013.

26. Johnson M, Moorhead S, et al. NOC and NIC linkages to NANDA-I and clinical conditions. Support in a critical reasoning and quality care. Iowa City: Elsevier; 2012.

27. Carpenito LJ. Nursing care plans \& documentation: Nursing diagnoses and collaborative problems. Philadelphia: Lippincott Williams \& Wilkons; 2009.

28. Ackley BJ, Ladwig GB, Swan BA, Tucker SJ. Evidence-based nursing care guidelines: Medical-surgical interventions. St. Louis: Mosby; 2011.

29. Park H. Identify core NANDA-I nursing diagnoses, NIC interventions, NOC outcome, and NNN linkages for heart failure. Int J Nurs Knowl 2014;25:30-8.

30. Chiappinotto S, Martin E, Santin C, Rigon LA. The patient with heart failure. Observational study with M. Gordon's model and NANDA-I, NOC and NIC taxonomies. Scenario Aniarti 2017;34:27-32.

31. Zampieron A, Silla A, Corso M. A retrospective study of nursing diagnoses, outcomes, and interventions for patients admitted to a cardiology rehabilitation unit. Int J Nurs Terminol Classif 2011;22:148-56. 